\title{
Solutions for changing production scale in the agricultural sector in Vietnam
}

\author{
Thi Hoai Nguyen ${ }^{1, *}$, and Duc Luan Nguyen ${ }^{2}$ \\ ${ }^{1}$ Graduate Academy of Social Sciences, 477 Nguyen Trai street, Thanh Xuan district, Hanoi, 10000, \\ Vietnam \\ ${ }^{2}$ Academy of Journalism \& Communication, 36 Xuan Thuy street, Cau Giay district, Hanoi, 10000, \\ Vietnam
}

\begin{abstract}
In this paper, the authors analyze the current situation of agricultural production in Vietnam and affirm that fragmentation is one of the basic causes leading to ineffective potentials and low labor productivity. Based on this, the authors propose a number of solutions to convert small-scale production to large-scale production in order to improve labor productivity and optimally exploit resources in the agricultural sector in Vietnam today.
\end{abstract}

\section{Introduction}

Since the beginning of the renewal period, Vietnam's agricultural production has had many positive changes, step by step overcome the fragmentation and small and gradually turn to commodity production. However, this transition is slow, not as expected, and not commensurate with the potential. Basically, Vietnam's agricultural production is still small and fragmented with obsolete and outdated farming tools and methods. In order to improve labor productivity and make optimal use of agricultural resources, it is necessary to synchronize solutions to switch to large-scale commodity production.

\section{Methods}

The authors use analytical and comparative methods to analyze materials and data, then comparing with the general development indicators of the country, thereby proving that Vietnam's agricultural production is still fragmented production with small-scale and low labor productivity. This requires the transition to large-scale production to effectively exploit the potential and improve labor productivity. With these methods, the authors have proposed and justified solutions for transition from small-scale agricultural production to large-scale production in Vietnam in the following years.

\footnotetext{
*Corresponding author: hoainguyengass@gmail.com
} 


\section{Results}

The land is considered as the most important agricultural means of production. When Vietnam entered the renovation period, the production force was not developed, manual production was still popular. Therefore, small ownership of land was not a factor that inhibited the development of the agricultural production force at this time. However, at present, the production force has made an important development associated with the process of industrialization and modernization, then the small and scattered ownership has become a factor hindering the development of the agricultural production force. Statistics in recent years show that: 14 million farm households still own 78 million plots. Vietnam is one of the countries with the lowest land per capita in the world with 0.25 ha, while in the world this index is 0.52 ha and in the region that is 0.36 ha [2].

The current allocation of the right to use small and dispersed plots to the farmers by the State has made the agricultural production materials not to be exploited with the highest efficiency and labor productivity low. In 2018, labor productivity in the field of agriculture, forestry, and fisheries was 39.8 million VND per one employee, while the average labor productivity in Vietnam was 102.2 million VND per one employee. This sector contributes only $14.68 \%$ of the gross domestic product (at current prices) but employs $37.7 \%$ of the total social labor (Statistical Yearbook of Vietnam 2018). There are many reasons for the small, scattered ownership of land in Vietnam. That is, the area of agricultural land is not much but the large population size, especially in the Northern provinces, makes the cultivation area per capita low. In the process of allocating agricultural land to farmers, the principle of equity must always be ensured, but in each given area, the fertility of agricultural land is not the same. Moreover, the distance from the plots to the residential areas is also different and it leads to the situation that each farmer household will receive many different fertile plots in different locations.

There are not only individual farmer households, smallholders but also enterprises of various economic sectors, different types of enterprises participating in agricultural production and business activities. However, regardless of the economic sector or type of business, businesses operating in the agricultural sector are also small in scale with a very limited number. In 2017, there were only 5463 agricultural businesses and related service activities of the total 560417 businesses. In which, there are 499 enterprises with the scale of less than 0.5 billion VND; 536 businesses with the scale from 0.5 to under 1 billion VND; 1806 enterprises with scale of from 1 to under 5 billion VND; 835 enterprises with the scale of from 5 to under 10 billion VND; 1151 enterprises with the scale of from 10 to under 50 billion VND; 367 enterprises with the scale from 50 to less than 200 billion VND; 126 enterprises with the scale of from 200 to less than 500 billion VND; 143 enterprises with the scale of 500 billion VND or more (Statistical Yearbook of Vietnam 2018).

Compared to the individual economy and small owners, businesses operating in the agricultural sector have a larger ownership scale. But if compared to other fields, most businesses operating in the agricultural sector are very small in scale. Out of 5463 enterprises operating in the field of agriculture and related service activities, only 1787 enterprises with the scale of over 10 billion VND. In the whole country, there are 5750 enterprises with the capital of 500 billion VND or more, of which only 143 enterprises operate in agriculture (Statistical Yearbook of Vietnam 2018). With such a small number of enterprises operating in the agricultural sector, it is very difficult to exploit the potentials of the agricultural sector. 2017 statistics show that the net revenue of the manufacturing of all enterprises operating in the agricultural sector and related service activities reached only 112963 billion VND (meanwhile, the total net revenue of production and business of all enterprises of all economic sectors in our country is 20664322 billion VND). Profit before tax of these enterprises is 4957 billion VND (meanwhile, profit before tax of all enterprises 
in all economic sectors in our country is 876676 billion VND) (Statistical Yearbook of Vietnam 2018). In general, net revenue and profit before tax of enterprises operating in the agricultural sector and related service activities are very low compared to other fields and compared to the common ground, even downtrend (9602 billion VND in 2010 to 4957 billion VND in 2017) (Statistical Yearbook of Vietnam 2018). That shows not commensurate with the potential of agriculture.

The current situation of small-scale and scattered agricultural production is hindering the process of applying science and bringing modern technology into agricultural production. This will negatively affect the development of agriculture towards large-scale commodity production.

The cause of this situation is that the level of agriculture is very low. It mainly bases on experience and tools, traditional and outdated production methods. This makes the production process too dependent on nature and leads to low productivity with high risk. On the other hand, one of the other reasons is due to investment resources, especially limited capital and science - technology, are not commensurate with the potential. The State has not yet created favorable mechanisms and policies to form a large-scale agricultural production. That situation requires Vietnam to synchronously implement a variety of different solutions to overcome existing shortcomings and weaknesses.

The first solution is to have policies to encourage and create convenient conditions for economic sectors and types of production and business organizations to operate effectively in the field of agriculture.

It means that besides implementing policies of equality between economic sectors and between types of enterprises, there must also be priorities and incentives to encourage economic sectors as well as production and business organizations to operate effectively. In fact, Vietnam is prioritizing and helping economic sectors and types of production and business (agricultural cooperatives) that are unable to effectively exploit production forces in the field of agricultural production. Therefore, the solution that the authors propose is to give priority, incentives, and promotions for economic sectors and types of enterprises that are capable of effectively using production forces, ie economic sectors, type of production business based on private and mixed ownership. By implementing this solution, production forces will be developed for profit or progress in business more effectively, will grow faster, and soon achieve the goals of socialism.

The second solution is to continue renewing the agricultural cooperative economic model to improve the efficiency of using collective-owned resources.

In the current conditions of Vietnam, the collective economy mainly exists under the cooperative model. This appeared in Vietnam about 60 years ago and is associated with the process of building socialism. It has played a huge role in the revolutionary cause of the Communist Party of Vietnam. However, over the years, this model has revealed many limitations even when moving from a model of collectivizing production materials to a joint-stock cooperative model, the cooperatives in Vietnam still show many weaknesses and have not promoted the resources of the collective ownership in general as well as collective ownership in agriculture in particular. Therefore, in order to develop the cooperative economy in Vietnam today, it is necessary to continue to innovate and in that process, it requires learning from experience in the world.

Around the world, the cooperative was born about 150 years ago. From these 150 years' practice, 9 principles of establishment and operation of cooperatives can be summarized as follows: 1. Self-help to each other; 2. Self-responsibility; 3. Self-management; 4. Each cooperative member has the same voting rights; 5 . Dual nature (a cooperative member is both the owner of the cooperative and a customer who buys (uses) the services of the cooperative); 6. Dual markets; 7. Dual ownership and dual accounting; 8. Dual supervision. In fact, there have been a number of cooperatives formed in Vietnam based on these 
principles, most notably the model of Quy Hien cooperative in Bao Thang district, Lao Cai province. This cooperative model is not a household economic negation and the cooperative ownership is not a replacement of household ownership but only a portion of the household's ownership being transformed into the cooperative ownership. This means that the cooperative does not eliminate and does not replace the role of the farmer's household head in self-accounting but by providing input services at lower prices, higher quality, implementing agricultural production planning, and organizing product consumption of cooperative members.

From the experience of the world and the reality of Vietnam, the authors found that during the process of building and developing cooperatives today, the following issues need to be paid attention:

First of all, the cooperative must be considered as an economic organization that exists in parallel with the individual economy to support the individual economy of farmers.

Since the introduction of the Cooperative Law in 1996, a joint-stock cooperative model has been established. However, cooperatives still do not work effectively with this new model because farmers do not really have many benefits when they become shareholders of cooperatives. In addition, cooperatives do not have effective support for farmer households and there is no mechanism for a close association between cooperatives and farmer households. That reality requires continuing to adjust the cooperative model so that the cooperatives co-exist and support the individual economy of farmer households, at the same time, there is a mechanism of rigorous attachment between cooperatives and households farmers from input to output of the production and business process in order to bring practical benefits to both sides.

Secondly, dual ownership and dual accounting need to be done in agricultural cooperatives.

That is, the members own their assets for production and business and at the same time own a part of the cooperative's assets and profits. As a business, the cooperative provides its members with paid services to cover costs and maintain operations. Therefore, the activities of cooperatives must be accounted for. Meanwhile, each cooperative member has their own property as well as production and business, so they must account for their own production and business activities, and take responsibility for their own profits and losses. Therefore, when assessing the performance of a cooperative, it is not only to assess how much a cooperative earns profits but also to assess how much the income each cooperative member earns by using the services provided by the cooperative. After that, it should be compared with the income of non-cooperative households.

Thirdly, it is necessary to ensure the voluntariness in the process of forming agricultural cooperatives.

Vietnam needs to consider cooperatives as equal to other types of production and business. Therefore, the State only plays the role of developing mechanisms, policies, and laws for the establishment and operation of cooperatives. This process must be voluntary by farmers on the basis of laws, mechanisms, and policies of the State. When the cooperatives bring real benefits to the members, it will be voluntarily participated by the farmer households. This will be the most important condition to ensure the sustainable development of cooperatives.

The third solution is to proactively organize agricultural production in the form of a joint-stock company.

The issue of land accumulation, increasing the scale of ownership of agricultural production materials has been concerned and addressed by the Communist Party of Vietnam and the State of the Socialist Republic of Vietnam. This is reflected in the Resolution of the 7th Central Conference of the Party Central Committee (Session X) on the issue of agriculture - farmers - rural areas, in the Resolution of the 6th Conference of 
the Party Central Committee (Session XI), and especially in the 2013 Land Law. However, the current land guidelines and policies in Vietnam generally face a conflict between policy groups that facilitate the process of land concentration and accumulation in order to increase economic efficiency, and on the other side are policy groups aiming to ensure equity, social stability and avoid the gap between rich and poor [4]. This conflict requires Vietnam to implement a policy of land accumulation without leading to conflicts of interest between the parties. In order to implement this problem well, the State should only focus on creating necessary mechanisms, policies, and regulations when accumulating land. The remaining work will be decided by farmers who have fields and individuals who want to accumulate land.

According to the authors, in order for the process of land accumulation and concentration as well as the expansion of the ownership of production means in the agricultural sector to be effective and bring benefits to all participants, it is recommended that promote deployment under the model of an agricultural joint-stock company.

The model of an agricultural joint-stock company which is proposed by the authors is a model with the share contributions of farmer households and enterprises. Farmers do not have capital, so they will contribute their shares which are lands. On the basis of the vast land formed by the contributions of farmer households, enterprises invest capital, science, and technology in carrying out production and business activities. The agricultural jointstock company differs from cooperatives in that it negates the existence of a farmer's individual economy, nor does it exist in the form of dual ownership and dual accounting as the cooperative in which it exists in the form of share ownership of shareholders, so it cannot operate under the Cooperative law but must operate under the Enterprise law and comply with the organizational and operational principles of a joint-stock company. At the moment, the farmer is a shareholder of an agricultural joint-stock company, which means co-ownership of this company. Their income will be income from shares and wages for the company they own shares. We need to build mechanisms for farmers who have stock to become organic labor of these companies.

The model of an agricultural joint-stock company mentioned above will face some difficulties when applying, especially the ownership issue. Once a share has been contributed in the form of land, of course, the land will no longer be the private property of the farmer and become joint ownership of an agricultural joint-stock company. That means the land as well as all production materials, all resources of the company will be owned by all shareholders. This is something that not all farmer households are willing to accept. However, if applied in practice, this model will open up opportunities for agricultural development in the direction of large-scale commodity production and this will create advantageous conditions to promote the application of science and technology to production. Since then, brands of agricultural goods that can compete in the market will be formed. It will be better if this model has the share of scientists or research institutes because their participation will help the process of applying science and technology to production faster and more effectively.

The fourth solution is to enhance direct links between farmer households and businesses.

This is one of the solutions to promote the process of accumulation and concentration of agricultural production materials and contributes to the formation of large-scale agricultural production in Vietnam.

The reality of agricultural production in Vietnam now appears a model of direct linkage between farmers and enterprises through contracts, in which enterprises directly provide inputs to farmers and support product consumption for them. The advantage is that the ownership and the land use rights are not changed, but the land can still be accumulated, the production materials can be gathered, the farmers are supported with both inputs and 
outputs and the company has become a highly competitive brand meeting the requirements of modern goods production. Of course, as the authors have stated, this model is only suitable for places where farmers have a lot of land and ponds. Therefore, they do not necessarily have to join cooperatives or agricultural joint-stock companies, and it is still possible to conduct large-scale commodity production. However, for small and fragmented land areas, farmers have little land and means of production, it is difficult to apply this model.

In essence, the process of land accumulation and concentration is a process of renewal of ownership in agriculture and the process of social labor redistribution. It creates advantageous conditions for the efficient exploitation and use of labor forces, land, and other resources in the agricultural sector.

The fifth solution is to continue renewing policies to attract investment and to focus on the attraction and efficient use of foreign-owned resources in the agricultural sector.

In 2010, the Government issued Decree 61/2010 ND-CP to attract businesses to invest in agriculture and rural areas but it is ineffective. Subsequently, in 2013, the Government issued Decree No. 210/2013/ND-CP. Compared with Decree 61/2010, Decree 210/2013 has added new points as follows: clearly defining responsibilities of implementing agencies; process and conditions of receiving support are clear and transparent; there is a written commitment to support when the enterprise completes investment, it is entitled to a policy for the enterprise to invest safely; small grants (such as training, advertising, etc) are deducted from the expenses of the business when settling taxes and do not need direct support from the budget; and there is direct support from the central budget to localities facing budget difficulties to build essential infrastructure. Decree 210/2013 also ascertains the level of support for each sector. In addition, the Decree also stipulates the degree of support for enterprises that directly train unskilled workers in factories and research, produce and test science and technology [3].

However, businesses operate with the goal of profitability, so they will decide to invest if they are profitable, not to receive support money. Therefore, in order to attract investment, especially foreign direct investment in the field of agricultural production, in addition to the solutions and incentives shown in Decree 210, the authors believe that it is necessary to allow investors to receive a capital contribution by land use rights from collectives and individuals and to permit foreign-invested enterprises to rent the land of households and individuals. In fact, this is a bottleneck hindering both investors and farmers. Foreign investors cannot invest, cannot promote production and business activities or put capital and technology into production if they are not allowed to rent the land of households and individuals; farmers also cannot participate in the large-scale production process associated with modern science and technology if they are not allowed to contribute capital with land use rights.

In short, to mobilize and effectively use investment resources, especially foreign direct investment, the problem is not how much they support, but most importantly, the difficulties and barriers are removed, especially the barriers related to land use rights and creates favorable conditions for businesses.

\section{Conclusion}

The achievements that Vietnam's agriculture has acquired in the years of implementing the renovation policy are undeniable. However, it must also be straightforward to admit that the current agricultural production in Vietnam is still limited due to its fragmentation and smallness. In order to effectively exploit resources and to improve labor productivity, Vietnam's agricultural production needs a transition from small scale to large scale. The solutions that the authors propose in this article are to successfully implement that 
transition.

\section{References}

1. T.H. Nguyen, D.L. Nguyen, The impact of the ownership renewal process on the development of productive forces in the agricultural sector in Vietnam today (National Political Publishing House, Hanoi, 2016)

2. P. Le, National Assembly of Vietnam (2019)

3. Huong Ly, Gorvement review (2013)

4. Xuan Than, Economics review (2013)

5. V.L. Chu, Collective ownership and collective economy in a socialist-oriented market economy in Vietnam (National Political Publishing House, Hanoi, 2006)

6. D.K. Nguyen, Theoretical basis and practice in continuing to improve the land policy in Vietnam today (Labor Publishing House, Hanoi, 2008)

7. T.H. Nguyen, Philosophy Review 4 (2015) 